\title{
Rapid spread of the wasp spider Argiope bruennichi across Europe: a consequence of climate change?
}

\author{
Sabrina Kumschick • Stefan Fronzek • \\ Martin H. Entling • Wolfgang Nentwig
}

Received: 30 June 2009 / Accepted: 3 December 2010 / Published online: 28 June 2011

(C) Springer Science+Business Media B.V. 2011

\begin{abstract}
Numerous species are expanding their ranges towards the North Pole, a pattern that is usually explained with climate change. However, few studies have actually tested the potential role of climate in such range expansions. Here, we studied the wasp spider Argiope bruennichi, which has multiplied its range in Central and Northern Europe during the 20th century and is still spreading. Using current and historical climate data, we analysed whether this spread can be explained by climate warming, increasing cold tolerance or if it is unrelated to temperature. Spatial partial regression showed that the spread of A. bruennichi into formerly cooler areas is independent of spatial autocorrelation, indicating that it is driven by temperature. Some aspects of the spread, as e.g. the patchy distribution at the beginning of the century are likely to be relicts of climate fluctuations before our study period. From the middle of the 20th century until the 1980s, A. bruennichi was recorded from gradually cooler climates, while temperature was relatively constant. This indicates that $A$. bruennichi either increased its cold tolerance or that the spread continued with a time lag following an earlier warming event, due to dispersal limitation. In the last two decades, temperature rose sharply. The temperatures at which $A$. bruennichi was newly recorded increased as well, indicating that the spider is dispersal limited and that the spread will continue even in the absence of further climate warming.
\end{abstract}

\section{Introduction}

Human transport of species beyond their native range counts as the main cause of biological invasions. However, environmental change such as global warming can cause species to

Electronic supplementary material The online version of this article (doi:10.1007/s10584-011-0139-0) contains supplementary material, which is available to authorized users.

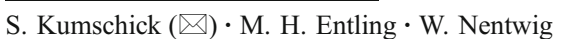
Institute of Ecology and Evolution, Community Ecology, University of Bern, Baltzerstrasse 6, 3012 Bern, Switzerland e-mail: sabrina.kumschick@iee.unibe.ch

S. Fronzek

Finnish Environment Institute, Research Programme for Global Change, P.O. Box 140, 00251 Helsinki, Finland 
spread even without initial displacement (Parmesan et al. 1999; Walther et al. 2002). Global temperature has increased by approximately $0.6^{\circ} \mathrm{C}$ over the past century with two main periods of warming, the first between 1910 and 1945 and the second from 1976 onwards (IPPC 2001). Europe has warmed more than the global average, with an increase of $0.95^{\circ} \mathrm{C}$, and winter temperatures have increased more than those in summer (European Environmental Agency 2004). These recent climatic changes have affected a broad range of organisms with diverse geographical distributions (Walther et al. 2002). A great variety of responses to this warming are known and many studies show in particular the shift of species ranges towards the North Pole and to higher altitudes (e.g., Parmesan et al. 1999; Parmesan and Yohe 2003).

The wasp spider Argiope bruennichi (Scopoli 1772) (Araneae: Araneidae) extended its range northwards during the 20th century. Originally it occurred in the Mediterranean part of Europe plus in a few isolated locations in warmer regions of Central Europe (e.g., Wiehle 1931). Therefore, A. bruennichi is often described as a thermophilic species (Guttmann 1979). Around 1930, A. bruennichi started to spread and to expand its range north- and eastwards in Europe. This phenomenon has been shown for several countries and regions (e.g., Scharff and Langemark 1997; Jonsson and Wilander 1999; Jonsson 2004; van Helsdingen 2007) but a comprehensive analysis has so far been lacking.

Here, we assemble data on distribution and spread of $A$. bruennichi on a continental level and present the most complete compilation of its spread in Europe from 1901 to 2006. We compare the spatial distribution of $A$. bruennichi with temperature conditions for different time periods during the 20th century. Current and historical climate data allow us to compare temperatures in newly colonised areas with temperature development at locations of primal records. With this method we can classify the role of climate warming for the spread of A. bruennichi. We aimed to test three climate-related hypotheses concerning the recent spread of A. bruennichi: 1) A. bruennichi has spread independent of climate; 2) the spider tolerated colder climates; 3 ) the spread was facilitated by climate warming.

\section{Materials and methods}

\subsection{Study species and records}

Argiope bruennichi is one of the most conspicuous spiders in Central Europe. It is easily recognized by the transverse black and yellow stripes on its abdomen; also its orb web is unique for Central and Northern Europe since it usually includes a zigzag stabilimentum. Thus, A. bruennichi is very easy to determine even for laymen. A chronological survey of this species is eased by the fact that it cannot be mistaken with any other species in Central and North Europe. Furthermore it is unlikely that it has been overlooked in the past because of its large size, conspicuous appearance and life history.

We collected records of $A$. bruennichi in 21 European countries from various sources: 6 catalogues, 81 publications, 3 databases of national arachnological societies and 10 personal communications of private data collections (see Appendix S1). Only records giving traceable locations and/or geographic coordinates were used. When the time of record was not mentioned, we used the year of publication instead. We pooled the data for 1901-1949, then for decades until 1999, and for 2000 to 2006. We had to pool the first half of the 20th century, because one of the largest databases (ARAGES, Germany) did not provide information on the exact year of observation for this period. The period 2000-2006 
was selected because climate data was available only until 2006. Some countries had to be dropped due to limited data availability (Ukraine, Moldavia, Romania, Russia, Belarus, Faroe Islands, Andorra). Further, we excluded from the analyses the Mediterranean countries from which A. bruennichi has colonised Central and Northern Europe (Italy, France, Spain, Portugal, Bulgaria, Serbia, Croatia, Turkey, Greece, Bosnia-Herzegovina, Montenegro, Slovenia, Albania, Macedonia).

Despite of the conspicuous appearance of $A$. bruennichi, the absence of records does not reliably indicate the absence of the species, so we work with presence-only data. Furthermore, the tendency to report the species from a site is obviously reduced after its first record. For this reason we took two approaches in this study. First, we considered locations only at the time of records ('new records' hereafter). Still, some sub-datasets confirm that after initial colonisation, wasp spiders were still present in following years/periods (e.g. Egger 1995; Jonsson 2004; Van Helsdingen 2007). Therefore, we secondly considered locations from the time of first record onward, assuming that the spiders stayed at the sites where they were once found, so under assumption of total tenacity (accumulated records).

\subsection{Climate data}

We obtained monthly averages of temperature from 1901 to 2006 on a regular grid system with a spatial resolution of $0.5^{\circ} \times 0.5^{\circ}$ from the Climate Research Unit (CRU) of the University of East Anglia (pre-release of version CRU TS 3.0; Ian Harris pers. comm.; Mitchell and Jones 2005; New et al. 2002). Then we calculated means for the time periods 1901-1949, 1950-1959, 1960-1969, 1970-1979, 1980-1989, 1990-1999 and 2000-2006 for the following variables: mean annual temperature (T; Supplementary material, Appendix S3), temperature of the coldest month (TCM) and temperature of the warmest month (TWM). To account for the fact that also within-year variation in temperature might play a role in species distributions (Řezáč et al. 2007; Fang and Lechowicz 2006) we took continentality (difference between temperature of warmest and coldest month; Mikolaskova 2009 ) as measure of climatic variability (CON). CON increases as one moves from the coast towards inland areas and from west to east in Europe (Supplementary material, Appendix S3).

\subsection{Analysis}

Although there are biological reasons why different temperature variables might affect the distribution of $A$. bruennichi differently (minimum temperature might influence mortality of eggs, for example), both, temperature of the coldest $(r=0.94)$ and the warmest moth $(r=$ 0.80 ) are strongly correlated with mean annual temperature in our study area. Thus, we chose mean annual temperature, because it is the measure of temperature most often considered. Through visual inspection of the data, we found that the records that made up the lower $4 \%$ of the temperatures were largely situated in mountainous regions. As there is no reason why the species should be more cold tolerant in mountains than in lowlands, we assume that these records are from warm (valley) situations within heterogeneous grid cells with low average temperature, and that the average temperature of the grid cell does not reflect the temperature at the location where A. bruennichi was found. We accounted for such untypical situations by deleting records that lay outside the $96 \%$ confidence interval of temperature across all grids for the respective decade.

Development of $\mathrm{T}$ in grid cells where the wasp spider was initially present and so found in the first period (1901-1949) is further on called $\mathrm{T}_{\text {old }}$. Thus, $\mathrm{T}_{\text {old }}$ was calculated for the 
same set of grids for each time period. $\mathrm{T}$ at grid cells of new records is called $\mathrm{T}_{\text {new }}$ and $\mathrm{T}$ at successfully colonized locations, under assumption of complete site tenacity is called $\mathrm{T}_{\mathrm{acc}}$ (accumulated for all periods since the first record).

To characterise the general trend in temperature, we plotted $\mathrm{T}_{\text {old }}$ over all the time periods. To find out whether the spread of $A$. bruennichi was related to temperature we tested whether $\mathrm{T}_{\text {new }}$ developed differently than $\mathrm{T}_{\text {old }}$. Therefore we calculated the differences between $\mathrm{T}_{\text {old }}$ and $\mathrm{T}_{\text {new }}$, further on called $\mathrm{T}_{\text {diff. }}$ We tested whether the new records of $A$. bruennichi come from colder areas than existing records using a one-sample $t$-test on $\mathrm{T}_{\text {diff }}$ in $\mathrm{R}$ version 2.6.1 ( $\mathrm{R}$ Development Core Team 2007). Significant outcomes were interpreted as directed spread, i.e. as non-random with respect to temperature. However, decreasing temperatures at new locations may also result from the general direction of the spread to more northern and consequently cooler areas, even if temperature is not an underlying factor. To exclude this possibility, we performed spatial partial regression in SAM (version 3.0; Rangel et al. 2006). We tested if there was a significant trend in $T_{\text {diff }}$ over time independent of its spatial direction (Supplementary material, Appendix S2).

We calculated $\mathrm{CON}$ for the same sets of records as $\mathrm{T}\left(\mathrm{CON}_{\text {old }}, \mathrm{CON}_{\text {new }}\right.$ and $\mathrm{CON}_{\text {acc, }}$, respectively) and analysed it analogously. We also tested whether there are differences between $\mathrm{CON}$ in the old locations of record and the newly occupied locations using a onesample $t$-test on $\mathrm{CON}_{\text {diff }}$ (analoguous to $\mathrm{T}_{\text {diff }} ; \mathrm{CON}_{\text {new }}-$ mean $\left(\mathrm{CON}_{\text {old }}\right)$ ) in $\mathrm{R}$ version 2.6.1 (R Development Core Team 2007). We also performed spatial partial regression in SAM to test for spatial autocorrelation with respect to $\mathrm{CON}_{\text {diff }}$ (Supplementary material, Appendix S2).

\section{Results}

In total we collected 3,033 records of A. bruennichi from 19 countries. By the end of 2006, the only investigated European countries without records of $A$. bruennichi were the Republic of Ireland and Iceland. Of the total 1,658 grids of the study area, 391 have been occupied by $A$. bruennichi until the end of the study period.

At the beginning of the 20th century, A. bruennichi was distributed patchily in the study area. Afterwards, A. bruennichi has not just expanded towards northern regions of Europe, it has also closed the gaps between its formerly isolated populations (Fig. 1). In the first half of the 20th century, A. bruennichi was present in eight countries. In the 1950s, the first wasp spider was newly found in Austria (Kritscher 1955). First records from the Czech Republic date around 1970 (Buchar and Růžička 2002). Sweden and the Netherlands followed in the 1980s (Jonsson and Wilander 1999; van Helsdingen 2007). In the 1990s, it was first reported for Denmark and began to spread in Sweden (Andersen and Enghoff 1993; Jonsson 2004). Furthermore, nearly entire Central Europe was colonised. After 2000 A. bruennichi has been found in 19 of 21 countries with new records from Norway, Finland and Estonia and from Lithuania and Latvia, spread was already reported.

\subsection{Temperature}

Concerning climate warming in the studied grid cells, $\mathrm{T}_{\text {old }}$ has increased by around $1.1^{\circ} \mathrm{C}$ over the last century and also temperature in whole Europe has increased (Supplementary material, Appendix S3). After an initial phase of nearly constant temperature until the 1980s, temperature started to heavily increase in the 1990s (Figs. 2 and 3). During the period of constant $\mathrm{T}_{\text {old }}$ until the $1980 \mathrm{~s}, \mathrm{~T}_{\text {acc }}\left(-0.7^{\circ} \mathrm{C}\right)$ and $\mathrm{T}_{\text {new }}\left(-1.0^{\circ} \mathrm{C}\right)$ both decreased (Fig. 2). This 

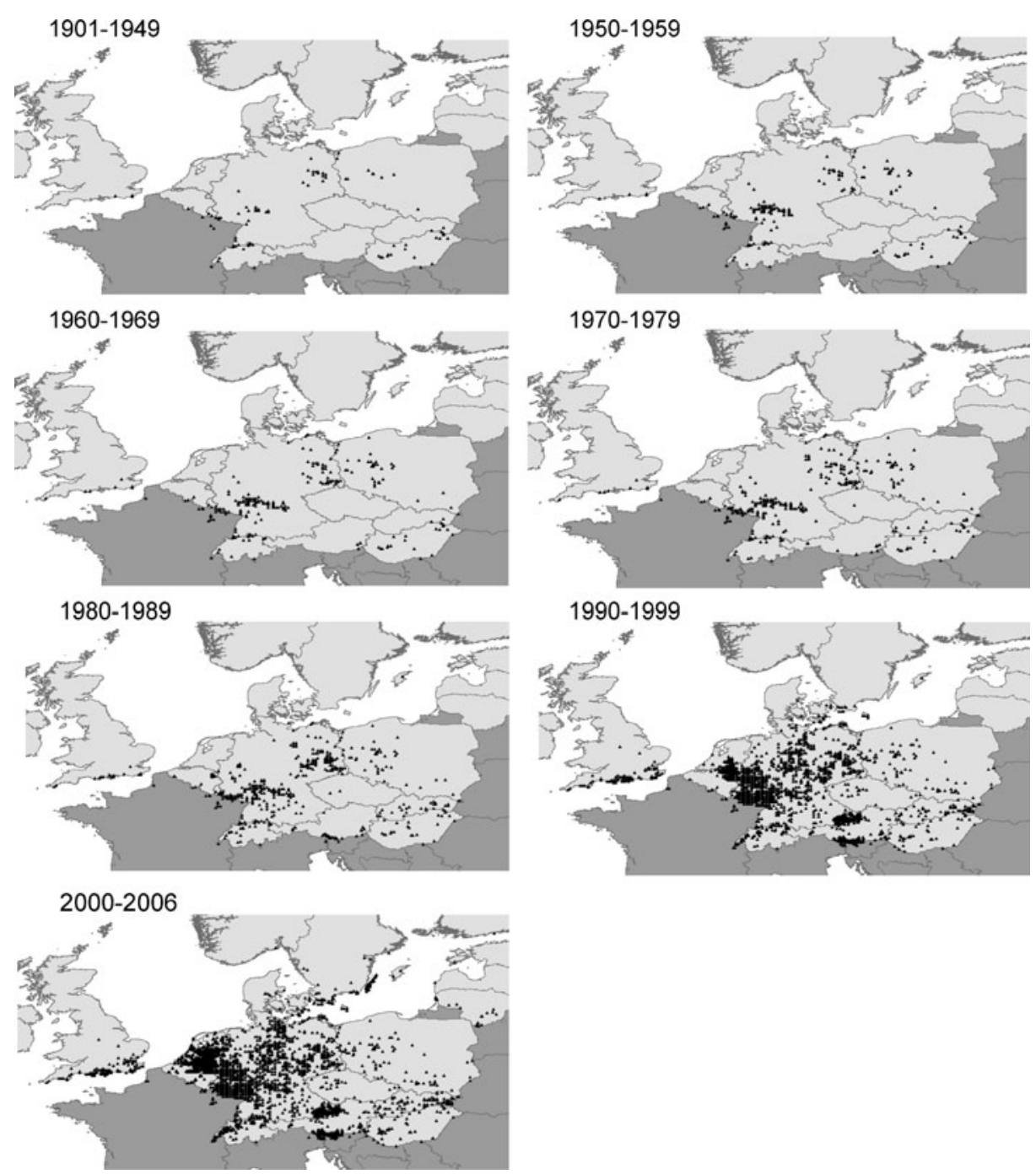

Fig. 1 Distribution of A. bruennichi in Central and Northern Europe during different time periods. Each triangle represents one record; accumulated records are shown. Light grey countries are countries investigated; dark grey countries were dropped

means that from the 1950s onwards, newly occupied grids had cooler temperatures than those already occupied in the first half of the 20th century. From the 1990s until the end of the study period in 2006, temperatures of the colonised area increased around $0.6^{\circ} \mathrm{C}\left(\mathrm{T}_{\text {acc }}\right)$ to $0.9^{\circ} \mathrm{C}\left(\mathrm{T}_{\text {new }}\right)$, while $\mathrm{T}_{\text {old }}$ increased by $1.1^{\circ} \mathrm{C}$. Thus, temperatures in areas newly occupied by $A$. bruennichi increased at a slower rate than the general temperature.

Temperature at initial locations and temperature in the grid cells currently occupied by $A$. bruennichi differed significantly in all time periods, with temperature at initial locations being warmer than at newly occupied locations (Table 1). Furthermore, these differences increased over time (Fig. 4) and this increasing difference between $T_{\text {new }}$ and $T_{\text {old }}$ was robust towards 
Fig. 2 Development of temperature differences between areas colonised by $A$. bruennichi at different times. Solid squares denote the development of mean annual temperature in grids where the wasp spider was originally found. Open circles show temperatures in grids of accumulated records at the time of the respective records (assuming that the spider persisted in all locations after its first record). Grey dots show temperatures at new records. Error bars are standard errors of the mean

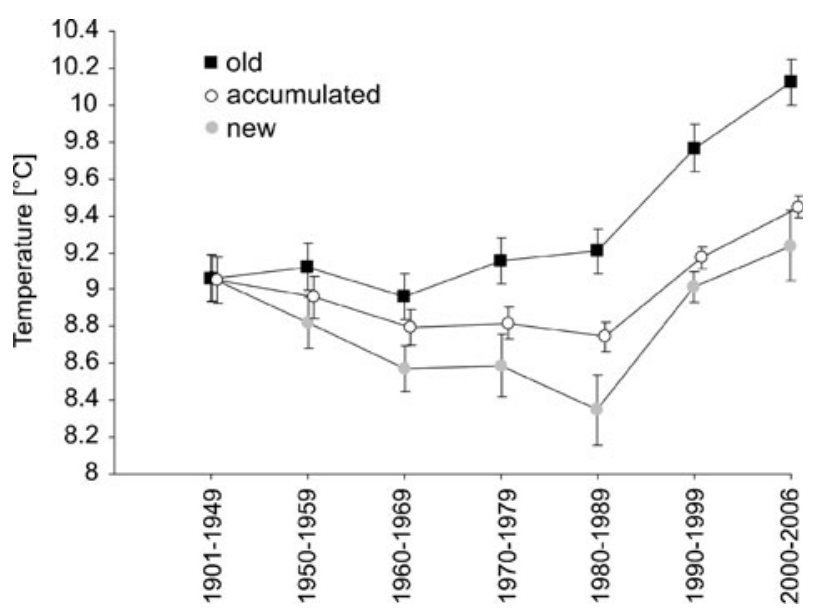

spatial autocorrelation (Supplementary material, Appendix S2, Table S2.1). In the last two study periods, $\mathrm{T}_{\text {old }}$ increases very fast whereas $\mathrm{T}_{\text {acc }}$ and $\mathrm{T}_{\text {new }}$ increased at a slower rate.

\subsection{Continentality}

Continentality at initial locations and in the grid cells currently occupied by A. bruennichi differed significantly in half of the time periods, with clear differences in the last two decades (from 1990 on; Table 2). There was no clear trend of general development of continentality at old locations and in Europe generally (Supplementary material, Appendix S3). However, newly colonized locations became increasingly less continental than old locations over time (Fig. 5). This spread towards less continental locations was robust towards spatial autocorrelation (Supplementary material, Appendix S2, Table S2.2).

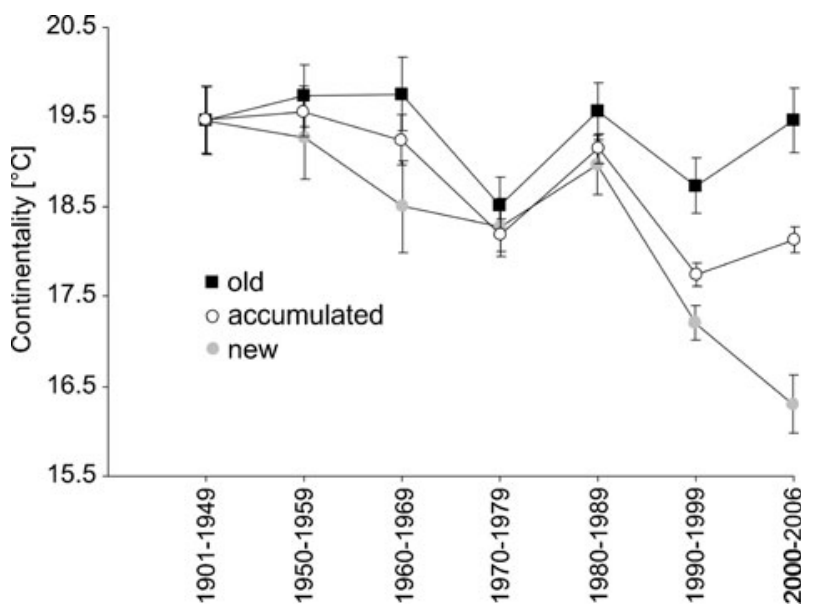

Fig. 3 Development of continentality in areas colonised by A. bruennichi at different times. Solid squares denote the development of continentality (TWM-TCM) in grids where the wasp spider was originally found (old records). Open circles show continentality in grids of accumulated records at the time of the respective records (under assumption of tenacity). Grey dots show continentality at locations of new records. Error bars are standard errors of the mean 
Table 1 One-way $t$-test of differences between general temperature development at locations of primal records $\left(\mathrm{T}_{\text {old }}\right)$ and temperature at locations of record during the period of first record $\left(\mathrm{T}_{\text {new }}\right)$

\begin{tabular}{lllr}
\hline Time period & $t$ & $d . f$. & $p$ \\
\hline $1901-1949$ & 0 & 50 & 1 \\
$1950-1959$ & -2.20 & 22 & 0.038 \\
$1960-1969$ & -3.22 & 27 & 0.003 \\
$1970-1979$ & -3.33 & 29 & 0.002 \\
$1980-1989$ & -4.54 & 40 & $<0.001$ \\
$1990-1999$ & -9.11 & 166 & $<0.001$ \\
$2000-2006$ & -4.66 & 50 & $<0.001$ \\
\hline
\end{tabular}

\section{Discussion}

\subsection{Temperature relation and continentality}

Since the beginning of the 20th century A. bruennichi has spread widely into central and northern Europe. The systematic decrease of mean temperature in newly occupied areas relative to the original records is in accordance with climatic warming as a driver of this recent range expansion (Parmesan et al. 1999). As $\mathrm{T}_{\text {diff }}$ increased over time it is possible that $A$. bruennichi might have changed its physiology and e.g. increased its tolerance towards low temperatures at the high latitude limit (Hampe and Petit 2005). Still $A$. bruennichi has spread into areas with lower continentality while continentality at locations of old records did not change systematically with time. This suggests that winter temperature might still be a limiting factor in the distribution of $A$. bruennichi. Therefore we rather suggest that $A$. bruennichi has colonised areas that had become inhabitable at an earlier time period, but could not be colonised at that time due to dispersal limitation. However, in the last two study periods temperature in general rose very fast whereas temperature at locations of $A$. bruennichi records increased at a slower rate. This indicates that climate warming accelerated the spread of $A$. bruennichi.

Fig. 4 Difference of temperature between newly occupied locations and old locations. Error bars are standard errors of the mean

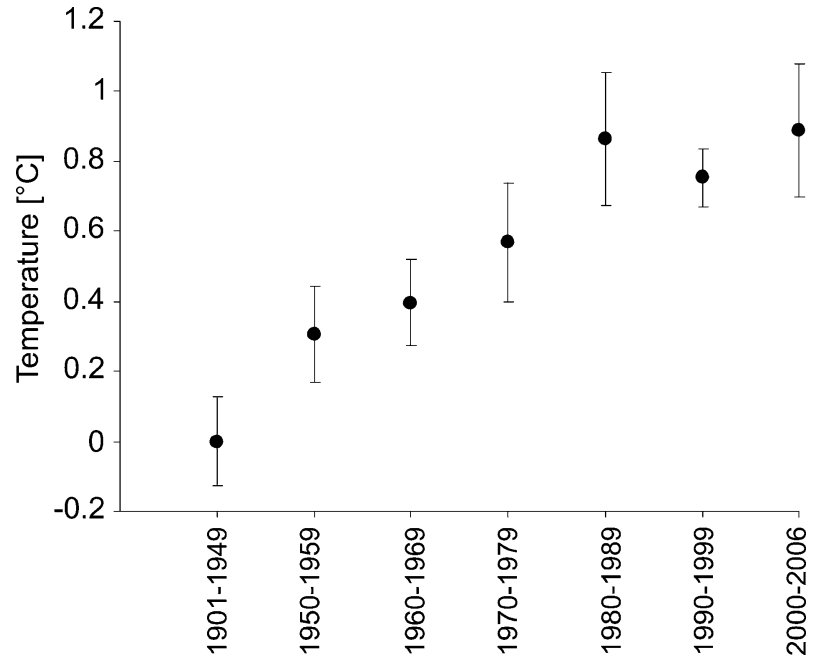


Table 2 One-way $t$-test of differences between development of continentality at locations of primal records $\left(\mathrm{CON}_{\text {old }}\right)$ and continentality at locations of record during the period of first record $\left(\mathrm{CON}_{\text {new }}\right)$

\begin{tabular}{lllr}
\hline Time period & $t$ & d.f. & $p$ \\
\hline $1901-1949$ & 0 & 50 & 1 \\
$1950-1959$ & -1.02 & 22 & 0.320 \\
$1960-1969$ & -2.44 & 27 & 0.022 \\
$1970-1979$ & -0.74 & 29 & 0.464 \\
$1980-1989$ & -1.78 & 40 & 0.082 \\
$1990-1999$ & -7.94 & 166 & $<0.001$ \\
$2000-2006$ & -9.84 & 50 & $<0.001$ \\
\hline
\end{tabular}

Furthermore, independently of the current climate change, climate has been warming since the end of the little ice age, i.e. since the 19th century, enabling many species to enlarge their distribution range from their refuges to the current range (for further examples, see Hewitt 1999). For many species, this natural spread has not yet reached its end and we still observe that they enlarge their distribution area. Thus, for a given species, it may be difficult to decide whether a current range expansion is still part of post-glacial natural spread, due to the current climate change, or a combination of both.

\subsection{Cold tolerance}

In the first half of the 20th century, the average temperature in grid cells where $A$. bruennichi was found was about $9.1^{\circ} \mathrm{C}$, whereas in the $1960 \mathrm{~s}, 70 \mathrm{~s}$ and $80 \mathrm{~s}$, the average temperature in newly occupied grid cells was between 8.3 and $8.6^{\circ} \mathrm{C}$. Consequently, $A$. bruennichi colonized regions which were significantly colder than its original range. Furthermore, despite temperature in general did not increase in Europe in the 1960s and 70s (Luterbacher et al. 2004), A. bruennichi continued spreading at that time. Possibly, populations north of the Alps developed a more pronounced cold tolerance and/or better hibernation abilities than Mediterranean A. bruennichi populations during the last centuries

Fig. 5 Difference of continentality between newly occupied locations and old locations. Error bars are standard errors of the mean

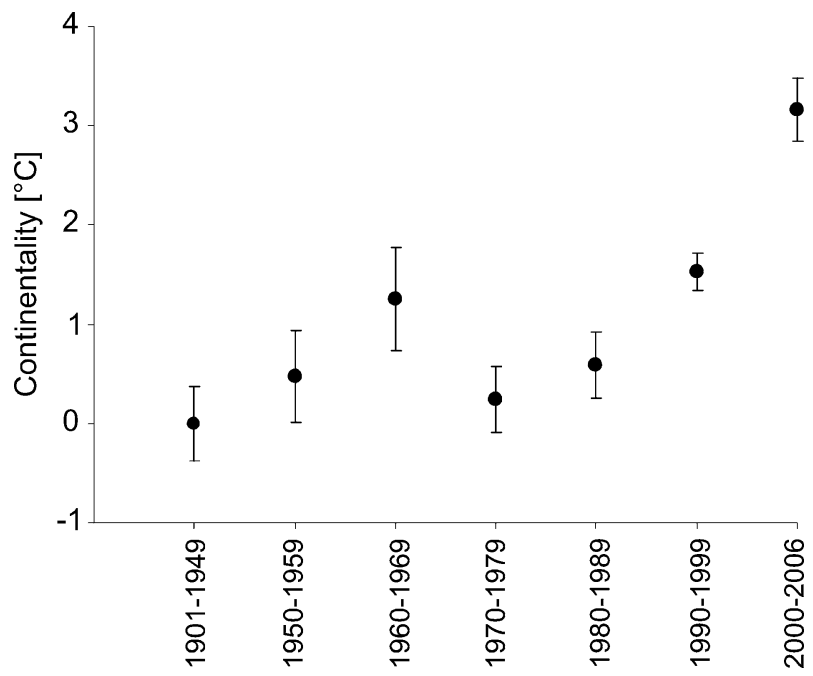


(Hampe and Petit 2005). This could have facilitated further spread without increasing temperature. However, only few data on the cold tolerance of A. bruennichi are available (Köhler and Schäller 1987), and continentality in newly occupied locations is significantly lower. As A. bruennichi is a thermophilic species, high temperatures should not be a problem for the spider. Therefore it is likely that temperature in the coldest month is limiting and consequently, continentality decreases significantly in new locations. So the spread towards cooler areas in the 1960 s and 70 s can be better explained by an earlier warming event in concert with dispersal limitation.

\subsection{Natural spread and dispersal limitation}

Some aspects of the distribution and spread of $A$. bruennichi are likely to result from climatic fluctuations prior to anthropogenic climate change. Temperatures in Europe peaked in the late medieval times, then dropped during the little ice age, and since then rose again (Fig. 6). As temperatures during the medieval warm period were about as warm as today over a prolonged time period, it is likely that A. bruennichi was distributed over large parts of Central and Northern Europe at that time. In the 15th century the medieval warm period had been replaced by a cooler period which lasted, with some short interruptions, until the late 19th century. Probably, A. bruennichi disappeared from most areas of Central Europe during that time, and remained only in some suitable refuges which formed the basis of the patchy distribution of $A$. bruennichi at the beginning of our study period. Furthermore, this overall withdrawal may have facilitated the development of more tolerance to colder environments as mentioned above.

The warming process since the late 19th century has probably initialised the spread of $A$. bruennichi at the beginning of the 20th century. Because of this slow but steady warming

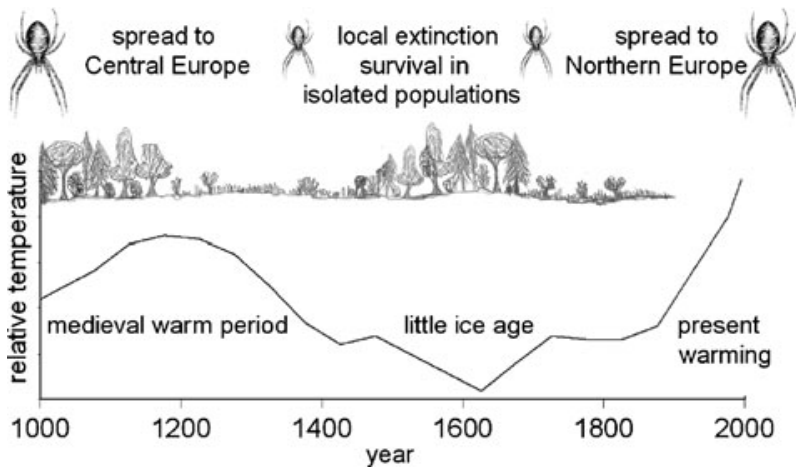

Fig. 6 Temperature change (relative values according to IPCC data), landscape appearance (schematically) and possible spread of Argiope bruennichi during the last 1,000 years in Central Europe. During the medieval warm period human population and agricultural pressure on landscape increased, leading to a minimum of forest and prevailing open landscapes which enabled A. bruennichi to colonise these areas. A subsequent cold period ("little ice age"), famines, plague and wars (such as the 30 Years' War) reduced the human population size in the 17th century to a minimum which allowed forests to grow again. Climate and landscape change were unfavourable for A. bruennichi which disappeared in most parts and only survived in isolated populations at suitable locations. In the 18th century, with an increase of human population and beginning of the industrialisation process, forest disappeared again (high demand for construction material and energy), landscapes opened and together with present warming, A. bruennichi spread from its southern main habitat but also from northern isolated populations. Reforestation of the last century is not shown. Historical data and events from Nentwig (2005) 
process, locations where A. bruennichi was found in the first half of the 20th century had been colder before. Therefore it is very likely that $A$. bruennichi had to tolerate colder temperatures already before our study period. This would imply that it was not an induced cold tolerance which enabled $A$. bruennichi to colonise new regions, but that it is limited in its dispersal abilities and was not able to occupy suitable locations exactly in time. This phenomenon is for example known for trees (Davis 1976; Svenning and Skov 2007; Svenning et al. 2008), where due to dispersal limitation many species have not yet reached equilibrium with climate since the last glaciation.

A similar phenomenon can also be observed from the 1990s onwards. Although $A$. bruennichi would be able to occupy colder areas, temperatures at locations of records increase as temperature in general rises too fast for $A$. bruennichi to follow. This means that areas of suitable temperature are too far away for the wasp spider to reach in such a short time period. A comparable phenomenon is also known for some butterflies (Warren et al. 2001), where the authors studied responses of British species to climate and habitat change. Only very mobile generalist species do not lag behind climate, but even fairly mobile generalists do. Therefore, the latter are, besides climate, restricted in its distribution by their limited dispersal abilities. Also A. bruennichi appears to having not yet reached all suitable areas because of dispersal limitation and most probably many other dispersal limited arthropods are in the same situation. As a consequence, the area expansion of $A$. bruennichi is probably far from being finished. Furthermore, with climate warming and increasing temperature, even more suitable areas are created for such dispersal limited arthropods which might lead to the area expansion of many species in the near future.

Acknowledgements Thanks to Nikolaj Scharff and an anonymous reviewer for helpful comments on the manuscript. Many thanks to ARABEL, ARAGES, CSCF, Aloysius Staudt, Christian Komposch, Christo Deltshev, Csaba Szinetár, David Roy, Frederick Hendrickx, Holger Frick, Ioan Duma, Katarzyna Zieba, Koen van Keer, Lars Jonsson, Maria Chatzaki, Marija Biteniekyte, Niclas Fritzén, Nikolaj Scharff, Nina Polchaninova, Peter van Helsdingen, Piet Tutelaer, Robert Bosmans, Róbert Gallé, Seppo Koponen, Voldemars Spungis, Walter Egger, Wojciech Solarz, Zuzana Krumpalova for providing valuable literature and data. Special thanks to Christian Kropf for his help in searching literature. We acknowledge financial support from the EC through the FP 6 Integrated Project ALARM (Assessing LArge scale environmental Risks for biodiversity with tested Methods; GOCE-CT-2003-506675; www.alarmproject.net; Settele et al. 2005).

\section{References}

Andersen NM, Enghoff H (1993) Stribetæge og hvepseedderkop-flotte nye danske dyrearter. Dyr I Natur og Museum 1:11-13

Buchar J, Růžička V (2002) Catalogue of spiders of the Czech Republic. Peres Publishers, Praha

Davis MB (1976) Pleistocene biogeography of temperate deciduous forest. Geosci Man 13:13-26

Egger W (1995) Neues zum Vorkommen der Wespenspinne Argiope bruennichi (Scopoli) in Kärnten. Carinthia II 185:201-204

European Environment Agency (2004) Impacts of Europe's changing climate. European Environment Agency Report no. 2 (http://www.eea.eu.int).

Fang JY, Lechowicz MJ (2006) Climatic limits for the present distribution of beech (Fagus L.) species in the world. J Biogeogr 33:1804-1819

Guttmann R (1979) Zur Arealentwicklung und Ökologie der Wespenspinne (Argiope bruennichi) in der Bundesrepublik Deutschland und den angrenzenden Ländern (Araneae). Bonn Zool Beitr 30:454-486

Hampe A, Petit RJ (2005) Conserving biodiversity under climate change: the rear edge matters. Ecol Lett $8: 461-467$

Hewitt GM (1999) Post-glacial re-colonization of European biota. Biol J Linn Soc 68:87-112 
Intergovernmental Panel on Climate Change (2001) In: Houghton JT, Ding Y, Griggs DJ, Noguer M, van der Linden PJ, Dai X, Maskell K, Johnson CA (eds) Climate change 2001: the scientific basis. Contributions of Working Group I to the Third Assessment Report of the Intergovernmental Panel on Climate Change. Cambridge University Press, Cambridge

Jonsson LJ (2004) Getingspindeln, Argiope bruennichi, etablerad och sprider sig norrut i Sverige. Entomologisk Tidskrift 125:117-120

Jonsson LJ, Wilander P (1999) Är getingspindeln, Argiope bruennichi, etablerad i Sverige? Entomologisk Tidskrift 120:17-21

Köhler G, Schäller G (1987) Untersuchungen zur Phönologie und Dormanz der Wespenspinne Argiope bruennichi (Scopoli) (Araneae: Araneidae). Zool Jb Syst 114:65-82

Kritscher E (1955) Araneae. In: Catalogus Faunae Austriae, Teil IX b: 1-56. Wien

Luterbacher J, Dietrich D, Xoplaki E, Grosjean M, Wanner H (2004) European seasonal and annual temperature variability, trends, and extremes since 1500. Science 303:1499-1503

Mikolaskova K (2009) A regression evaluation of thermal continentality. Geografie 114:350-362

Mitchell TD, Jones PD (2005) An improved method of constructing a database of monthly climate observations and associated high-resolution grids. Int J Climatol 25:693-712

Nentwig W (2005) Humanökologie. Springer, Heidelberg

New M, Lister D, Hulme M, Makin I (2002) A high-resolution data set of surface climate over global land areas. Clim Res 21:1-25

Parmesan C, Yohe G (2003) A globally coherent fingerprint of climate change impacts across natural systems. Nature 421:37-42

Parmesan C, Ryrholm N, Stefanescu C, Hill JK, Thomas CD, Descimon H, Huntley B, Kaila L, Kullberg J, Tammaru T, Tennent WJ, Thomas JA, Warren M (1999) Poleward shifts in geographical ranges of butterfly species associated with regional warming. Nature 399:579-583

R Development Core Team (2007) A language and environment for statistical computing. R Foundation for Statistical Computing, Vienna

Rangel TFLVB, Diniz-Filho JAF, Bini LM (2006) Towards an Integrated Computational Tool for Spatial Analysis in Marcoecology and Biogeography. Glob Ecol Biogeogr 15:321-327

Řezáč M, Řezáčová V, Pekár S (2007) The distribution of purse-web Atypus spiders (Araneae: Mygalomorphae) in central Europe is constrained by microclimatic continentality and soil compactness. J Biogeogr 34:1016-1027

Scharff N, Langemark S (1997) Hvepseedderkoppen, Argiope bruennichi (Scopoli), i Danmark (Araneae; Araneidae) [Argiope bruennichi (Scopoli) in Denmark (Araneae; Araneidae)]. Entomologiske Meddelelser 65(4):179-182

Settele J, Hammen V, Hulme P, Karlson U, Klotz S, Kotarac M, Kunin W, Marion G, O'Connor M, Petanidou T, Peterson K, Potts S, Pritchard H, Pysek P, Rounsevell M, Spangenberg J, Steffan-Dewenter I, Sykes M, Vighi M, Zobel M, Kühn I (2005) ALARM-Assessing LArge-scale environmental Risks for biodiversity with tested Methods. Gaia 14:69-72

Svenning JC, Skov F (2007) Could the tree diversity pattern in Europe be generated by postglacial dispersal limitation? Ecol Lett 10:453-460

Svenning JC, Normand S, Skov F (2008) Postglacial dispersal limitation of widespread forest plant species in nemoral Europe. Ecography 31:316-326

van Helsdingen PJ (2007) De Wespspin Argiope bruennichi in Nederland. from www.naturalis.nl/wespspin

Walther GR, Post E, Convey P, Menzel A, Parmesan C, Beebee TJC, Fromentin JM, Hoegh-Guldberg O, Bairlein F (2002) Ecological responses to recent climate change. Nature 416:389-395

Warren MS, Hill JK, Thomas JA, Asher J, Fox R, Huntley B, Roy DB, Telfer MG, Jeffcoate S, Harding P, Jeffcoate G, Willis SG, Greatorex-Davies JN, Moss D, Thomas CD (2001) Rapid responses of British butterflies to opposing forces of climate and habitat change. Nature 414:65-69

Wiehle H (1931) Araneidae. Tierwelt Deutschlands 23:1-136 